\title{
THREADING BETWEEN THE RELIGION \\ CLAUSES
}

\author{
IRA C. LUPU*
}

I

A number of constitutional provisions point in more than one direction. This is true of the First Amendment's Religion Clauses, ${ }^{1}$ which enjoin both establishment of religion and prohibitions on its free exercise; the Second Amendment, ${ }^{2}$ which focuses on a collective interest in well-regulated militias as well as individual rights to bear arms; and the Suspension Clause, ${ }^{3}$ which protects the writ of habeas corpus even as it creates criteria for the writ's suspension. Interpretation of such constitutional provisions might take the form of radical subordination of one of the pair of competing themes, or, alternatively, it might tend toward the ground that integrates and accommodates these apparently divergent values. What is surprising to behold is how often legal scholarship on these subjects chooses the former route over the more balanced, lawyer-like, and textually respectful approach of taking all parts of the relevant provisions into account.

The articles in this symposium by Professors Randy Lee and Marci Hamilton represent subtle illustrations of this phenomenon. ${ }^{4}$ Professor Lee claims that the Clinton Administration's concern for religious liberty and free exercise values, as manifested in its position on partisan political activity by taxexempt religious organizations, is inadequate. ${ }^{5}$ Professor Hamilton, on the other hand, claims that the Clinton Administration's solicitude for free exercise values, as revealed in a host of episodes she cites, is excessive and, hence, insensitive to Establishment Clause values. ${ }^{6}$ These two efforts at critique of the Clinton Administration bring to mind nothing so much as Goldilocks: Lee's porridge burns the tongue, and Hamilton's chills the belly. To make matters

Copyright (C) 2000 by Ira. C. Lupu

This comment is also available at http://www.law.duke.edu/journals/63LCPLupu.

* Louis Harkey Mayo Research Professor of Law, The George Washington University.

My thanks to Paula Zimmerman, of the class of 2000 at the George Washington University Law School, for assistance with research in connection with this essay.

1. U.S. CONST. amend. I.

2. Id. amend. II.

3. Id. art. I, $\S 9$.

4. See Randy Lee, When A King Speaks of God; When God Speaks to a King: Faith, Politics, Tax Exempt Status, and the Constitution in the Clinton Administration, 63 LAW \& CONTEMP. PROBS. 391 (Winter/Spring 2000); Marci A. Hamilton, Religion and the Law in the Clinton Era: An AntiMadisonian Legacy, 63 LAW \& CONTEMP. PROBS. 359 (Winter/Spring 2000).

5. See generally Lee, supra note 4.

6. See generally Hamilton, supra note 4. 
worse, neither offers the crucial perspective of comparison of this Administration with any of its predecessors. A careful review of the overall record suggests that the Clinton Administration has been more solicitous of the Religion Clauses as a whole than can normally be expected of elected national officials and their appointees.

\section{II}

Professor Lee's article is singularly focused on the Clinton Administration's decision to revoke the tax-exempt status of the Branch Ministries Church. ${ }^{7} \mathrm{He}$ argues that religious entities may have a special religious mission to accomplish in the political arena, by way of their capacity to "speak truth to power" and thereby hold political leaders to standards of morality. $\mathrm{He}$ also argues that conditioning tax exemption upon compliance with the rules limiting the campaign activity of churches unconstitutionally burdens the churches' religious freedom. ${ }^{9}$

Professor Lee's choice of target is peculiar. First, he is aiming at the wrong institution. The rules about which he complains find their home in the Internal Revenue Code $^{10}$ enacted by Congress, and not in any particular policy decision of the Clinton Administration.

Second, he attacks the Administration for bias in its enforcement of the Code's restriction because political appearances at churches by President Clinton and others did not provoke the same sort of response from the Internal Revenue Service ("IRS") as did the anti-Clinton advertisement paid for by the Branch Ministries Church. ${ }^{11}$ Bias correction in and of itself, however, would not necessarily result in the empowerment of churches. Whatever enforcement bias may have been present, it could have been cured by enforcing the restriction more widely rather than more narrowly. If enforcement were broadened, the complaint about administrative partisanship-permitting the churches hospitable to a candidate for public office to have her in their pulpits, while squelching those religious groups hostile to the candidate from attempting to defeat her-would vanish, and the total sum of church participation in politics would decrease.

Third, the claim that enforcement by the IRS of the restriction had been motivated by political partisanship - that is, that the Administration had been using the tax exemption rules in an attempt to silence its religiously motivated political enemies-is heavily and clearly belied by the history of IRS

7. See Branch Ministries, Inc. v. Rossotti, 40 F. Supp.2d 15, 21 (D.D.C. 1999) (upholding revocation of church's tax exemption on grounds of violating restrictions on political campaigning by tax-exempt organization).

8. Lee, supra note 4 , at $408,414-25$.

9. See id. at 404-13.

10. See 26 U.S.C. $§ 501(c)(3)$ (1999) (entities "organized and operated exclusively for ... religious purposes ... which do not participate in, or intervene in (including the publishing or distributing of statements) any political campaign on behalf of any candidate for public office" are tax exempt).

11. See Lee, supra note 4, at 394-404. 
enforcement patterns, carefully recited by the district court in the Branch Ministries decision. ${ }^{12} \quad$ For many years, long predating the Clinton Administration, the IRS had drawn a line between churches that invited political candidates to their pulpits in the time leading up to Election Day, and religious organizations that had employed their own tax-exempt resources to reach out to those beyond their congregations with an explicit pro- or anticandidate message. ${ }^{13}$ The IRS had never enforced the prohibition on partisan political activity against those religious entities that invited candidates to speak to congregations, even in those cases in which electronic media foreseeably would cover and transmit to the general public both the candidate's message and the religious setting in which it had been uttered. ${ }^{14}$ Indeed, the Branch Ministries opinion reports a total of sixty-five occasions, concerning candidate visits to religious institutions, upon which the agency had taken no action. ${ }^{15}$ Among the political visitors enumerated were some quite prominent incumbents and challengers of both major parties, including Bill Clinton, Newt Gingrich, Jesse Jackson, and Oliver North. ${ }^{16}$

By contrast, the IRS had a consistent policy of enforcement in cases in which religious organizations engaged in outreach to non-adherents with the express purpose of urging the election or defeat of a particular candidate. ${ }^{17}$ The district court took the highly unusual step of permitting discovery into the enforcement practices of the IRS,$^{18}$ yet the Branch Ministries Church could come up with absolutely nothing that suggested the Clinton Administration or any of its predecessors had administered these rules in a spirit of political partisanship, or had interpreted them overbroadly so as to squelch political involvement by religious institutions. If anything, the record suggested significant underenforcement-whether out of respect for religious institutions, concern for the sensitivity of such enforcement efforts, or a consensus between the major political parties that it was in both of their interests to allow fairly liberal church participation in political campaigns.

Fourth, the particular speech that led to trouble for the Branch Ministries Church is hardly a good example of the unique voice of religious institutions. Although the advertisement (appended to Professor Lee's paper) led with the admonition to Christians to "beware," followed by a warning that Christians should "not put the economy ahead of the Ten Commandments," the particulars of the advertisement were couched in terms suggestive of the work of spinmeisters of the Republican National Committee rather than a careful attempt at developing religious truth. The anti-Clinton charges in the ad

12. See Branch Ministries, 40 F. Supp.2d at 21-22.

13. See id.

14. See id.

15. See id.

16. See id. at 21.

17. See id. (citing two cases in which IRS revoked tax exemptions of religious organizations for similar conduct).

18. See id. at 17-18. 
included an assertion that then-Governor Clinton "[s]upport[ed] abortion on demand" and "[s]upport[ed] the homosexual lifestyle, and want[ed] homosexuals to have special rights." Abortion on demand has long been a right wing code for government-subsidized abortion and abortion for minor females without parental notice or consent. The "homosexual lifestyle" is a purposefully ambiguous term for both homosexuality per se and a charge of promiscuous homosexuality with which cultural conservatives have stereotyped gay men. The leaders of the Branch Ministries Church surely have a right to hold and express these views, but their claim to be able to do so with taxexempt contributions, while their political opponents must use after-tax dollars to fight back, is considerably less persuasive when one notes that the message is slur and slogan rather than a good faith effort at Biblical exegesis. ${ }^{19}$

Professor Lee's assertion that the governmental interest in this context is to maintain the voice of faith in this society is lovely in its Brennan-esque inversion of government and individual interests, ${ }^{20}$ but it misses entirely the point of the restriction on partisan political activity by all tax-exempt charitable institutions. Whatever special treatment religious organizations may be able to claim in other contexts, ${ }^{21}$ the area of political activity is one in which the claim to the constitutional uniqueness of religion is unusually weak, and the claim to equal participation by all is unusually strong. ${ }^{22}$ A policy of permitting churches, but not other tax-exempt organizations, to use tax-deductible contributions to help elect candidates to government offices positively contradicts Establishment Clause values, as the Supreme Court has elaborated them in cases like Texas Monthly, Inc. v. Bullock. ${ }^{23}$

Professor Lee's discussion of the Branch Ministries litigation does suggest a noteworthy observation about religion in the Clinton Administration, though it does not seem to be the point he has in mind. Contrary to Professor Hamilton's insinuations that the Clintonites are all too friendly to the religion-favoring

19. In very small print, the ad makes reference to Biblical verses in connection with each of its antiClinton assertions. While some of the verses are on point, others seem only remotely connected with the political charges made. The ad cites, for example, Exodus 20:14 ("You shall not commit adultery"), in support of its condemnation of homosexuals. See Lee, supra note 4, at 437 (reprinting Branch Ministries advertisement).

20. See Goldberg v. Kelly, 397 U.S. 254 (1970) (Brennan, J., for the Court, asserting that the state, as well as welfare recipients, has an interest in the very pre-termination hearings the state wishes to deny to recipients).

21. Claims of constitutional uniqueness on the part of religious organizations are ordinarily limited to "internal" matters of church property and personnel. See, e.g., Presbyterian Church v. Mary Elizabeth Blue Hull Presbyterian Church, 393 U.S. 440 (1969) (church property); EEOC v. Catholic University of America, 83 F.3d 455 (1996) (personnel). See generally Carl H. Esbeck, The Establishment Clause as a Structural Restraint on Governmental Power, 84 IOWA L. REV. 1 (1998); Kent Greenawalt, Hands Off! Civil Court Involvement in Conflicts Over Church Property, 98 ColuM. L. REV. 1843 (1998).

22. A long line of Supreme Court decisions confirms the constitutional significance of equal access to avenues of political input. See, e.g., Harper v. Va. State Bd. Of Elections, 383 U.S. 663 (1966) (invalidating poll tax in state elections); Reynolds v. Sims, 377 U.S. 533 (1964) (one person, one vote rule in legislative apportionment).

23. 489 U.S. 1 (1989) (holding that the Establishment Clause forbids Texas from exempting religious materials sold by religious organizations from state sales tax). 
dictates of the Religious Freedom Restoration Act of 1993 ("RFRA"), Professor Lee's account of the Justice Department's litigating positions reveals how the executive branch's day-to-day operations tend to undercut the proreligion political rhetoric of which the President seems so fond.

When the President signed RFRA in 1993, he did so with great fanfare and enthusiasm. ${ }^{25}$ Soon after the signing, Professor Michael Paulsen quite appropriately suggested that the actual operations of the Department of Justice and other federal agencies might be less religion-sensitive than the Act seemed to require, especially as reinforced by the President's support for it. ${ }^{26}$ A few years later, research I conducted after the Supreme Court's decision in City of Boerne v. Flores $^{27}$ strenuously supported the notion that federal and state governments were essentially ignoring the Act or attempting to gut it by urging courts to adopt narrow interpretations. ${ }^{28}$

The government's briefing of the Branch Ministries case in the district court is nicely illustrative of this tendency. In order to come under the Act, which the church argued required a religion-focused adjustment in the political advocacy restriction of section 501(c)(3) of the Internal Revenue Code, the Church had to demonstrate that the Code "substantially burden[ed]" 29 its religious practice. Its argument for so claiming was quite straightforward: The Code required the church to choose between tax-exempt status and what it claimed to be religiously motivated political advocacy. ${ }^{30}$ In light of the Supreme Court's decision in Sherbert v. Verner $^{31}$ - a decision that RFRA explicitly purported to "restore" ${ }^{32}$ - such conditioning of a government benefit upon surrender of the right to engage in religiously motivated conduct should have presented an indisputable case for a "substantial burden" under RFRA. ${ }^{33}$

24. 42 U.S.C. $\S 2000$ bb (1994). The Supreme Court invalidated the Act as applied to the states. See City of Boerne v. Flores, 521 U.S. 507, 532 (1997).

25. See Peter Steinfels, Clinton Signs Law Protecting Religious Practices, N.Y. TIMES, Nov. 17, 1993, at A18.

26. See Michael S. Paulsen, A RFRA Runs Through It: Religious Freedom and the U.S. Code, 56 MONT. L. REV. 249, 249-50 (1995).

27. 521 U.S. 507 (1997).

28. See Ira C. Lupu, The Failure of RFRA, 20 U. ARK. LITTLE Rock L.J. 575, 588-97 (1998) (documenting lack of administrative implementation of RFRA, and judicial narrowing of the Act by interpretation).

29. 42 U.S.C. $\$ 2000 \mathrm{bb}-1$ (1994).

30. See Branch Ministries, Inc. v. Rossotti, 40 F. Supp.2d 21, 26 (D.D.C. 1999).

31. 374 U.S. 398 (1963) (holding that the state had imposed an unconstitutional burden when it denied unemployment benefits to an employee who refused to work on Saturday, the Sabbath day of her faith).

32. 42 U.S.C $\$ 2000 \mathrm{bb}(\mathrm{b})(1)$ (1994).

33. Even with such a burden conceded, the government had the powerful argument remaining that it always has a compelling interest for denying religion-based exemptions from the tax code. See United States v. Lee, 455 U.S. 252, 257 (1982). The district court accepted this argument. See Branch Ministries, 40 F. Supp. 2d at 25. Of course, Congress had not exempted the tax code from the operation of RFRA, so this sort of blanket no-exemption policy was in some considerable respect inconsistent with the RFRA mechanism, which requires case-by-case exploration of religious versus governmental interests at stake in each conflict. Moreover, exemptions from restrictions on non-profit status do not necessarily raise the same concerns as exemptions from obligations to pay tax. 
Nevertheless, in its papers filed in the district court, the government strenuously controverted the argument that section 501(c)(3) burdened the religiously motivated conduct of the church. ${ }^{34}$ The government never mentioned Sherbert, or this case's resemblance to it, or Congress's stated intention to restore Sherbert's status as good law. Instead, the government sloughed off the church's argument as resting upon a tax-exempt's "operations" rather than belief. ${ }^{35}$ Operations are a synonym for practices, and Sherbert itself involved a religious believer's practice of adherence to the behavioral requirements of Saturday Sabbatarianism. Moreover, in both Sherbert and Branch Ministries, the relevant practices appeared to be religiously motivated.

In the Branch Ministries litigation, the government's back-of-the-hand treatment of RFRA most likely had no effect on the outcome. The district court was clearly and correctly disposed to find that the government had a compelling interest in eliminating political advantage for tax-exempt organizations. Nevertheless, the government's litigating posture was designed to minimize the force of the RFRA arguments. What the government did in this case is no doubt replicated with great frequency whenever the government is faced with a RFRA claim. In this regard, at least, Professor Lee has reminded us of a pattern of a day-to-day insensitivity of the executive branch to particular claims of religious institutions, perhaps explicable in terms of the gap between bureaucratic practice below and political values at the top.

III

This demonstration of the unreceptivity of the government's litigators to the claims of religion is in stark contrast with Professor Hamilton's extended indictment of the Clinton Administration's asserted overfriendliness toward religious institutions. ${ }^{36}$ Because she is so much more attentive to what the Administration says for public consumption than what it does in the trenches, she charges that the Clinton Administration lopsidedly favors the values of free exercise over the values of nonestablishment. ${ }^{37}$ In support of this thesis, she heaps together examples of pro-religious behavior without differentiating among them on constitutional grounds, mixes enthusiastic support by the Administration for certain policies together with the phenomenon of the Administration being dragged by Congress into measures the President tended to oppose, and ignores the Clinton Administration's weak record of administrative implementation of RFRA, which the President so

34. See Reply Brief for the Defendant in Further Support of her Motion for Summary Judgment or, in the Alternative, to Dismiss the Complaint for Failure to State a Claim Upon Which Relief Can Be Granted at 12, Branch Ministries, Inc. v. Richardson, 970 F. Supp. 11 (D.D.C. 1997) (No. CIV.A.1:95CV00724-PLF).

35. See id. at 14-15.

36. See Hamilton, supra note 4, at 364-71.

37. See id. at 360-61. 
enthusiastically signed. ${ }^{38}$ Indeed, the contrast between the Lee and Hamilton critiques highlights a basic question about the relationship among the President's political rhetoric, legislative agenda, and administrative performance in evaluation of the "record" of any presidential administration.

Professor Hamilton's critique of the Clinton Administration concerns its political behavior, not its legal or administrative practices, and behind her attack lies a theory about the appropriate relationship between religion and politics. Her view is that religious factions, and, in particular, broad coalitions within which religious factions congregate, are a danger to the Republic, and that Presidents labor under some sort of a quasi-constitutional obligation to resist the entreaties of such groups. ${ }^{39}$

Professor Hamilton characterizes her view as Madisonian, but the label fits somewhat uncomfortably with Madison's views. Madison was indeed concerned with the problem of faction in general, and religious faction in particular. ${ }^{40}$ Madison, however, was careful to distinguish among the causes of faction in which he included the divergence among human interests and the political liberty to pursue them, ${ }^{41}$ and the possible effects of faction in which he included the possibility of majority tyranny or private capture of public institutions. ${ }^{42}$ Because he believed normatively in political and religious liberty, and empirically in the divergence among human interests, he concluded that all attempts to restrict the cause of faction were foolhardy and tyrannical. Instead, he contended that the constitution must be structured to control the effects of faction. Hence, he argued that a large commercial republic, with a multitude of factions and a corresponding "multiplicity of [religious] sects," was the key to solving the problem of factions. ${ }^{43}$ To this he added legislative bicameralism and separation of powers in the federal government as additional checks on the ability of factions to use the levers of government to further private ends. ${ }^{44}$ In his own presidency, moreover, Madison distinguished between government support of churches as institutions, which he disfavored, and government support of religious faith and its ideals, which he occasionally was willing to support. ${ }^{45}$

Whether the political and intellectual lineage associated with Professor

38. See generally id. at 372-89.

39. See id. at 360-64.

40. The most famous exposition of these views is The Federalist No. 10. See THE FedEralist No. 10, at 77-84 (James Madison) (Clinton Rossiter, ed., 1961). For a full development of Madison's views on religious faction, see Christopher Eisgruber, Madison's Wager: Religious Liberty in the Constitutional Order, 89 Nw. U. L. REV. 347 (1995). Larry Kramer has recently shown that scholars in the 20th century paid far more attention to Madison's theory than did Madison's contemporaries. See Madison's Audience, 112 HARV. L. REV. 611, 611 (1999).

41. See THE FEDERALIST No. 10, supra note 40, at 78.

42. See id. at 80-84.

43. Id. No. 51, at 324 (James Madison).

44. See id. at 320-25.

45. See Donald Drakeman, Religion and the Republic: James Madison and the First Amendment, 25 J. CHurch \& ST. 427, 427-29 (1983). 
Hamilton's surname has subconsciously influenced her we cannot know, but her view of Madisonianism seems to me quite un-Madisonian. She misses the very point of Madison's reliance on structural checks when she criticizes the Coalition for the Free Exercise of Religion and President Clinton for his receptivity to the Coalition's agenda, which includes supporting religious liberty legislation and other political initiatives designed to involve political branches in promoting religious freedom. Nothing in Madisonian political theory justifies the attack on the Coalition; it is simply an association of factions, some from the civil liberties community and others from faith-based groups with a set of political aims. Surely this group deserves the same political liberty as other factions, and coalitions among factions, to pursue its ends. As Professor Hamilton recognizes, the fracturing of the coalition over issues pertaining to proposed religious liberty legislation is itself evidence to support Madison's belief that no permanent majority party or interest could sustain itself over time. ${ }^{46}$ That the ACLU and the Christian Legal Society can sometimes join forces and sometimes be directly opposed is a lovely illustration of the theory of shifting minority factions.

Moreover, nothing in Madisonian political theory imposes a duty upon the President to resist the entreaties of any particular faction, religious or otherwise. The structural checks upon which Madison relied were completely independent of the behavior of any particular President or faction which appealed to him. Even a President hell-bent on unconstitutionally establishing religion will still need the concurrence of Congress and the cooperation of the courts. Not even Professor Hamilton accuses President Clinton of such anticonstitutional designs, and, in any event, the courts disrupted RFRA, the boldest pro-religion scheme to which he was a party. ${ }^{47}$

Neither the existence of a particular faction, nor a pattern of presidential receptivity to it, is condemnable per se. If the Coalition for Free Exercise had existed in 1939, and had pleaded with then-President Roosevelt to take special efforts to help save European Jewry from Nazi persecution, surely we would not condemn the Coalition or the President if he responded sympathetically to its pleas. Presumably, it was the first "coalition for the free exercise of religion" that brought the Free Exercise Clause into being. Professor Hamilton's complaints about the Coalition for the Free Exercise of Religion, and President Clinton's positive response to it, thus can only sensibly rest on the substantive contents of their mutual agenda.

Here, one must proceed item-by-item, although I recognize that the thematic flavor of the whole package may exceed the sum of its parts. When Professor Hamilton's examples are unpacked and examined, the picture that emerges is definitely one of an Administration somewhat partial, as a political

46. See Hamilton, supra note 4 , at $370-71$.

47. They did so first by a set of narrowing interpretations, see Lupu, supra note 28, at 594-97, and, ultimately, by invalidation of RFRA as applied to the states, see City of Boerne v. Flores, 521 U.S. 507 (1997). 
matter, to the values of religious liberty, but not overtly or deeply hostile to the institutional concerns of the Establishment Clause-for example, dangerous alliances between government and powerful churches, and government espousal of sectarian creeds. In this comment, I cannot remark upon each and every one of Professor Hamilton's illustrations, but I do want to call attention to some particular features of her examples-in-chief.

\section{A. Executive Branch Actions}

Some of the Clinton Administration's joint ventures with the Coalition have been focused on clarifying the law that governs situations of conflict between private religious expression and other competing interests. The most noteworthy of these efforts produced the Guidelines on Religious Expression in the Public Schools. ${ }^{48}$ These guidelines, which have no legal force, but which nevertheless attempt to channel the judgment of school administrators and those who might adjudicate disputes over religion in public schools, are exquisitely sensitive to the Establishment Clause problem of officially sponsored religious speech in public schools, and the Free Exercise problems presented by student-initiated religious speech in the same setting. ${ }^{49}$ Although the Administration may well have promulgated the guidelines primarily for political credit, the guidelines may help forestall or resolve highly charged disputes over religious matters. To the extent the executive branch imprimatur on the guidelines facilitates these functions, this is a public service, ${ }^{50}$ not an unconstitutional intrusion into the field of religion. Indeed, the government at some level is inevitably involved in these disputes, and attempts at a set of principled and politically palatable resolutions are surely preferable to the demagoguery and litigation that often occur when local school boards take the lead.

As an occasion for the exertion of executive power, the Clinton Administration's guidelines on religious speech in the public workplace ${ }^{51}$ are even more defensible than the school guidelines; after all, the President is responsible for the conduct of that workplace. And here too, though one can always quibble about the particulars, conflicts between workers who desire to engage in their own religious speech at work and workers who prefer not to hear such speech require focused attention and reasonable rules to guide their resolution.

Of course, one can always ask why religiously motivated speech deserves to be singled out or to receive arguably more favorable treatment than sexually oriented speech or other controversial, non-work-related speech in the

48. Secretary's Statement on Religious Expression (visited Apr. 17, 2000) (Secretary Richard W. Riley) <http://www.ed.gov/Speeches/08-1995/religion.html>.

49. These problems will be aired in the Supreme Court this term in Doe v. Santa Fe Ind. Sch. Dist., 168 F.3d 806 (5th Cir.), cert. granted, 120 S.Ct. 494 (1999) (granting certiorari as to the validity of student-led prayer at high school football game).

50. Professor Hamilton's paper concedes this point, see Hamilton, supra note 4, at 387.

51. See 33 WeEKLy COMP. PRES. Doc. 1245 (Aug. 14, 1997). 
workplace..$^{52}$ Reasonable people can differ over whether religious themes are preferable to sexual themes for workplace chatter, but from the perspective of the captive but discomfited listener, the distinction will not hold. Moreover, the express permission in the guidelines for an employee-led prayer at weekly staff meetings, so long as the prayer is not reasonably perceived as state endorsement of religion, ${ }^{53}$ seems to go too far; a prayer in such settings, like an official prayer at school, is inherently coercive and no part of appropriate government business.

Without question, if the Establishment Clause generally forbids treating religion as a category of activity entitled to special attention by government, both the school guidelines and the workplace guidelines are eyebrow-raising. But if the core of Establishment Clause concerns are government actions that enhance institutional power of sectarian entities compared to others, or involve the state in sectarian advocacy, then guidelines of this sort seem a considerably lesser evil. At most, they empower religious individuals, to the limited detriment of those who do not share their beliefs or who think it inappropriate to express them in the workplace, without similarly empowering religious organizations. ${ }^{54}$ Viewed in their most troubling light, these guidelines recreate the inevitable tension between free exercise and nonestablishment, and resolve it with a tilt in the free exercise direction in the government workplace, and the nonestablishment direction in schools. This pair of offsetting biases seems quite consistent with the background law, ${ }^{55}$ and, though perhaps misguided, not a cause for the sort of constitutional alarms that Professor Hamilton has set off.

\section{B. The Supreme Court}

Professor Hamilton identifies three cases in the Supreme Court in which, she claims, the Administration has been insensitive to nonestablishment concerns. One of these, City of Boerne v. Flores, ${ }^{56}$ she knows very well because she successfully argued on behalf of the City against the constitutionality of RFRA as applied to the states. But the main ground of the argument in Boerne was not the Establishment Clause. Rather, the dispute's center of gravity was the federalism-based question of the scope of congressional power to expand the scope of constitutional rights under section five of the Fourteenth Amendment. ${ }^{57}$ Indeed, Professor Hamilton's opening line in the Supreme

52. The guidelines identify religious speech as deserving of treatment at least as good as, if not better than, speech on other subjects. See id.

53. See id.

54. The distinction between empowering individuals in their religious pursuits, and similarly empowering religious organizations, is one which the Supreme Court took seriously in Rosenberger $v$. Rectors of the Univ. of Va., 515 U.S..819, 834-36 (1995).

55. Compare Engel v. Vitale, 370 U.S. 421, 424-25 (1962) (invalidating official prayers in public schools) with Marsh v. Chambers, 463 U.S. 783, 791 (1983) (upholding prayer at opening of state legislative session).

56. 521 U.S. 507 (1997).

57. Although all parties fully briefed the Establishment Clause questions, only Justice Stevens indicated a view on them; he would have held RFRA to be a violation of that Clause, and hence 
Court, as I recall it, was "This case is not about religious liberty; it is about the scope of federal power." She succeeded in persuading the Court that the case was precisely about that. Although it is true that the United States argued that the Establishment Clause did not bar RFRA, this contention under current law is surely plausible. ${ }^{58}$ Right or wrong, such a government stance is hardly a mark of Establishment Clause insensitivity.

The other two cases mentioned by Professor Hamilton both involve federal aid programs that include sectarian schools among their beneficiaries. The Administration defended both programs. In Agostini v. Felton ${ }^{59}$ which involved public employees providing remedial instruction on-site in sectarian schools (among others), ${ }^{60}$ the Administration successfully argued for the overruling of Aguilar v. Felton. ${ }^{61}$ Here, too, the Administration did not adhere to the separationist party line, but took the entirely reasonable position that the aid program neutrally aided all children in low-income neighborhoods, and did so in a way that created virtually no risk of diversion of resources to religious instruction. Aguilar was a holdover from the regime of separationism in the extreme on issues of educational subsidies, and I cannot fault the Administration either for wanting this sort of aid to reach all low-income children or for believing that moving the program off-site to satisfy the Constitution was a needless waste of resources in exchange for little of constitutional value.

This term, in Mitchell v. Helms, ${ }^{2}$ the Administration has defended the constitutionality of a separate federal program that involves lending, among other things, books and computers to schools, public and private, sectarian and otherwise. Here, the contrast between the Administration's position and that of the private intervenors also defending the program is stark and illuminating. The intervenors argued that government may aid all schools, including sectarian ones, so long as the program is religion-neutral and the government itself is not engaged in religious indoctrination. ${ }^{63}$ By this theory, diversion of aid to religious uses by the school or its personnel-here, computers offer the most obvious possibility-does not implicate the Constitution, though it would in this

unconstitutional as applied to the federal government as well. See id. at 536-37 (Stevens, J., concurring).

58. The case that best supports the government's position is Corporation of Presiding Bishops v. Amos, 483 U.S. 327, 338-39 (1987) (holding that the Establishment Clause does not prohibit Congress from relieving religious organizations alone of otherwise generally applicable duties to not discriminate on the basis of religion). In my view, the Establishment Clause questions presented by RFRA are close and difficult. See Ira C. Lupu, The Case Against Legislative Codification of Religious Liberty, 21 CARDOZO L. REV. 565, 590-92 (1999).

59. 521 U.S. 203 (1997).

60. See id. at 208.

61. 473 U.S. 402 (1985) (holding that the Establishment Clause prohibited New York from sending public school teachers into parochial schools to provide secular, remedial education for disadvantaged children).

62. See Helms v. Picard, 151 F.3d 347 (5th Cir. 1999), cert. granted sub. nom Mitchell v. Helms, 119 S.Ct. 2336 (1999).

63. See Brief for Petitioners at 17-27, Mitchell (No. 98-1648). 
case violate the governing statute and regulations. By contrast, the United States argued in Mitchell that the statute's restrictions, which include antidiversion policies and a requirement that the aid not replace the school's own financial efforts, are necessary to rescue it from constitutional condemnation. ${ }^{64}$ Once again, separationists will disagree with the government's position, but, without question, it is narrowly drawn, sensitive to Establishment Clause concerns, and a great constitutional distance from the "pure neutrality" approach advanced by the intervenors and, more generally, by supporters of school voucher programs.

\section{The Congress}

Professor Hamilton offers a number of examples in which the Clinton Administration supported, or at least did not veto, congressional acts that favored religion. There is a difference, however, between enthusiastic support and refusal to veto. With respect to RFRA, Clinton indeed signed the bill with enthusiasm. ${ }^{65}$ But it had been introduced in the Bush Administration, and the work of pushing it had always fallen to the Coalition for Free Exercise and the bill's congressional sponsors. There is no sign that the Administration supports the current proposals for a Religious Liberty Protection Act ${ }^{66}$ designed to fill most of the gaps left after the Boerne decision. The Clinton Administration in practice has done little to promote or institutionalize the requirements of RFRA, which still applies to the federal government. The federal agencies rarely show cognizance of it, ${ }^{67}$ and, as suggested in my comments on Professor Lee's paper, federal government lawyers are not particularly solicitous of RFRA arguments.

The International Religious Freedom $\mathrm{Act}^{68}$ is a different story. Here, I cannot disclose my sources, but I have heard from a number of people in position to know-both within and without the government-that the Administration did not favor the Act, and worked quietly to defeat or dilute it. Why would any administration, after all, want imposed upon its foreign policy machinery the following burdens: (1) a set of required sanctions against other nations that offend principles of religious liberty, ${ }^{69}(2)$ a designated office within the State Department with a single issue mandate and constituency, ${ }^{70}$ and (3) an outside watchdog group looking over the Department's shoulder in its

64. See Brief for the Secretary of Education at 31-37, Mitchell (No. 98-1648).

65. See Steinfels, supra note 25, at A18.

66. See H.R. 1691, 106th Cong. (1999).

67. See Lupu, supra note 28 , at 589 (noting the paucity of references in the Federal Register to RFRA between 1993 and 1997). A follow-up search of the Federal Register, which I performed in 1999, produced no evidence of increased agency attention to RFRA.

68. 22 U.S.C. $\$ 6401$ (1999).

69. See id. $\S \S 6441-42$ (specifying presidential actions required in response to violations of religious freedom).

70. See id. $\S 6411$ (creating within the Department of State the position of Ambassador at Large for Religious Freedom). 
implementation of the Act's policies $?^{71}$ All of these mechanisms reduce the diplomatic flexibility that would otherwise obtain with respect to the U.S. response to religious persecutions by other nations. That the Clinton Administration acceded to these arrangements does bespeak the popularity of religious freedom as a principle of the lex Americana we would like to impose on the world, but does not suggest the Administration itself is willing to make religious freedom its number one priority in foreign relations. One need look no further than our long-standing policies toward China for evidence that religious liberty for all the world does not drive this Administration's diplomatic stance.

\section{The Zeitgeist}

Professor Hamilton is no doubt correct when she claims that President Clinton is openly religious in his personal life and in some of his political commitments. This personal religiosity, which may indeed be completely authentic, distinguishes him from his Republican predecessors Bush and Reagan, though of course it does not separate him from Jimmy Carter. She is also correct that the President does not openly admit that religion may be a force for evil as well as for good. Whether this is cognitive dissonance, good politics, or both, only the President and the nonexistent presidential psychiatrist might know.

However, with respect to one aspect of the Clintonian religious zeitgeist, Hamilton criticizes where, I think, only credit is due. She describes the President's view of religion as aimed at "unity" or "ecumenicism." "72 This seems right on the money and, when compared to many of his predecessors, completely admirable. Richard Nixon was a nasty anti-Semite, and Ronald Reagan used religion, particularly in relation to abortion, as a divisive wedge in politics. To the extent Bill Clinton has fully embraced the idea of religious tolerance in an increasingly diverse America, and has simultaneously opposed the religious coercion that would have been spawned by the Istook Amendment, ${ }^{73}$ he has been a force for good.

As Professor Marshall amply demonstrates in his piece in this issue, Stephen Carter vastly overstated the case in The Culture of Disbelief when he remarked that religion has been marginalized in the United States. ${ }^{74}$ Nevertheless, Professor Carter did identify the cultural chasm that separates secularists from people of deep religious faith in America. ${ }^{75}$ Presidential administrations, far more than the courts or Congress, can reshape the political culture with

71. See id. $\$ \S 6431-32$ (creating the Commission on International Religious Freedom).

72. See Hamilton, supra note 4 , at 364-65.

73. See William P. Marshall, The Culture of Belief and the Politics of Religion, 63 LAW \& CONTEMP. PROBS. 453, 464-65 (Winter/Spring 2000).

74. Id. at 457-61 (critiquing STEPHEN L. CARTER, THE CUlTURE OF DisBELIEF: HOW AMERICAN LAW AND POLITICS TRIVIALIZE RELIGIOUS DEVOTION (1993)).

75. Id. at 461-64 (explaining why religious people may perceive their views as marginalized in contemporary America). 
constant, thematic reinforcement of certain attitudes and concerns. Policies enacted during the Clinton years have not always been sympathetic to the cause of liberty, as critics of his criminal justice and immigration policies have frequently pointed out. ${ }^{76}$ This should come as no surprise; the Bill of Rights is designed to be an impediment to political majorities, and, as Michael Dukakis learned the hard way, Presidents are rarely lined up with the program of the ACLU. But this President, far beyond the record of his predecessors in this century, has been unusually supportive of the values of the Free Exercise Clause, and has sustained this effort without trampling the values of the Establishment Clause in the process. Paying substantive attention to both Religion Clauses, and threading so delicate a course between them, constitutes a pair of executive branch achievements worthy of commendation.

76. See, e.g., David Cole, Jurisdiction and Liberty: Habeas Corpus and Due Process as Limits on Congress's Control of Federal Jurisdiction, 86 GEO. L.J. 2481 (1998); Mark Tushnet \& Larry Yackle, Symbolic Statutes and Real Laws: The Pathologies of the Antiterrorism and Effective Death Penalty Act and the Prison Litigation Reform Act, 47 DUKE L.J. 1 (1997). 